INNA SAJTARLY,

Taras Shevchenko National University (Kyiv, Ukraine)

e-mail: inna.saitarly@gmail.com,ORCID 0000-0001-8253-4898

OLENA ISHCHENKO,

Taras Shevchenko National University (Kyiv, Ukraine),

e-mail: rebluesun@ukr.net, ORCID0000-0003-3832-2403

\title{
PHILOSOPHICAL PERSPECTIVE ON THE HUMANIZATION THROUGH A PRISM OF THE CIVILIZING PROCESS (BASED ON SOCIO-ANTHROPOLOGICAL IDEAS OF N. ELIAS AND M. FOUCAULT)
}

\begin{abstract}
The purpose of this publication is to considering the relationship between humanization and civilizing process, informing by Elias's and Foucault's studies. Theoretical basis of this research is founded on comparative analysis, phenomenological approach and generalization. Originality of this exploration is to the discovering of the similarities and also differences in Elias's and Foucault's viewpoints on civilizing process in the context of clarifying the basic meanings of humanization. Conclusions. As we believe one can point to some similarity in anthropological and sociocultural views of Elias and Foucault. First and foremost, both of them supported the thesis about of mutability of so-called human nature, that is, its conditionality by structural social changes. Secondly, Elias and Foucault are confident in that the history of cultures ("civilizations") is to the history of institutional struggle against human impulses and drives with a goal of their "modeling" in accordance with conventional social imperatives. Not only Elias, but also Foucault's poststructuralism call under question the civilizational interpretation of culture as such, that is any attempt to perspective on culture as a product exclusively of certain religious ideals and tradition. Elias proved convincingly that culture also depends on real social landscape, essential transformation of that does impact on essential transformation entire value system. And finally, within framework of these studies, the cultures are considered from point of view the degree of their civilizing in the sense of "humanizing", that is defined by them, first of all, as a long process of rationalization of behavioral patterns in terms of the strengthen of affective control and selfconstraint, and also as cultivating a specific aversion to the pain in its both physiological and moral meanings. In other words, the attitude of society and its culture to violence is the most significant marker of the level of its civilization, hence its humanization.
\end{abstract}

Keywords: civilizing process; humanism; humanization; culture; genealogy; power discourse; discipline; rationality.

\section{Introduction}

As well-known, in most philosophical studies is widely conventional that essential trait of the Civilizing Process is to be the movement, aimed at its humanization. It is in this movement, as some researchers admit, there is the distinctive attribute of the Civilizing Process, one can say, its progressive quality. The particularity of philosophical understanding of humanization is, supposedly, to be the clarifying what this phenomenon actually does means; what exactly it does relation to; and finally, what are the main its causes ("grounds").

In this connection the theory of the Civilizing Process, developed by Norbert Elias, and ideas of some poststructuralist authors, particularly of Michele Foucault are of the special interest, where we can try to find answers to the above issues, furthermore, whose works, as rightly note some authors, have not been more systematically compared and discussed. In additional, one should be noted that a topic of "humanization" in its correlation to the Civilizing process is the significant for a number of humanities, including sociocultural and philosophical anthropology. The emphasized interest of the representatives of the majority from sociocultural, primarily philosophical thought to issue of human immanence or to so-called new subjectivity, is obviously caused by whole number of reasons, which almost all postmodern philosophy tells about. Let us dwell on it in more detail.

\section{Purpose}

The purpose of this exploration is to considering the relationship between humanization and civilization, based on the analyzing of socio-cultural and anthropological ideas of Elias and Foucault.

\section{Statement of basic materials}

In the context of said above, one would like to pay attention on a scientific conference, where was held in 2010 years within frameworks of traditional for Western scientific communities "Foucault Studies". This time, the theory of Michele Foucault there were discussed from viewpoint of its similarity and distinction with the ideas of Norbert Elias. For instance, Sam Binkley and Cas Wouters, who directly participated in this conference, quite rightly pointed to that there are certain "similarities between these 
two great figures - they are both historical, they are both focused on the power, and on the history of what Foucault calls "the subject", and a "genealogy of subjectivity" (Binkley, Dolan, Ernst \& Wouters, 2010: 54-55).

We can agree with their statement, namely that "for Elias these were less a problem a power, and more linked to changes in the unique figurations of social groups" (p. 67). But, Cas Wouters (2010), for instance, claimed that "Foucault's analysis of power and government is not sociologically precise enough, it remains philosophically vague and abstract" ( $p .73)$. In this instance, we'd like to clarify, that "vague and abstract" philosophical analysis of Foucault was related to his quite critical account of the Civilizing process that was inherent not only Foucault, but almost the entire social philosophy of $20^{\text {th }}$ century.

Indeed, as well-known, Elias was convinced in more constructive role the higher classes ("Courtly Society") in the Civilizing Process, and in his workings, he, as a rule, didn't consider of repressive social technologies in their historical transformations, that was to the no less abstract then philosophy of Foucault. While Foucault, vice versa, paid more attention on "blood" mechanisms to induce each person to "order", namely, on the "ritual anatomy of tortures" and "disciplines", that is on the largely proliferation of "power discourses", which, from his view, were caused by tendency of power to total domination. Thus, both of these thinkers were quite complementary.

Such contemporary authors as Bowen Paulle and Mustafa Emirbeyer (2016) write about the fundamental similarities between Elias and Foucault, and state that Elias and Foucault made the same basic discovery about the same fundamental social process, which they call the social constraints towards improvement of process selfdiscipline.

Another contemporary researcher, namely Dan Alexandru Chita (2012) also points to the existence of "a clear identity" between Elias and Foucault, but in terms of what both define as the "constructing" of the modern civilized individual, and does support the thesis about "that in the building of the modern subject - political, ethical, psychological - they put forward a similar genealogy" - "a testimony of an even-changing subject" (p. 165-166). Having considered these theories, he concluded that the crux of civilizing process was that people became more selfcontrolled and self-restrained through lengthening and differentiating independent links between more and more people.

As Wouters, Chita believes that "Elias's main interest has always been to argue in favor of the pacification trait of the great confinement and almost never on the violence exerted by the visible hand of the state", while "Foucault is more interested in the relations of power" (Chita, 2012: 172-173). Nevertheless, when he notes that the question of designing the modern subject has not been directly posed before, he is wright partially, since he doesn't take into account such movements in the modern philosophy as psychoanalysis (which Elias, for example, often refers to) and so-called Frankfurt School.

Meanwhile, such a contemporary thinker as Georg Cavalletto (2016) points to strong influence on psychoanalysis in elaborating of Elias's theory of the civilizing process. In part, referring to Freud's "The Future of an illusion" and "Civilization and its Discontents", Cavalletto finds many similarities between psychoanalysis and other modern theories of civilization. Cavalletto reminds that Freud classifies the culture (civilization) as repressive social fact, and writes of its elite origin: "civilization is something, which was imposed on a resisting majority by a minority which understood how to obtain possession of the means to power and coercion" (Cavalletto, 2016: 12). Obviously, exactly these ideas of Freud will find additional grounding in further explorations Elias and Foucault.

It is worth to pay attention too, that the civilizing process is often discussed through prism of so-called postmodern dehumanization, as we believe, in order to developing of devices for creation the humanizing civilization. For example, a such contemporary explorer as Elohim JimenezLopes (2017) indicates to that nowadays the civilizations counter with problem of "the humanization of the dehumanized humans", hence with problem of searching and reification the possibilities to every human to "develop her/his personality with dignity."

Thus, the problem of humanization both a men and societies hasn't lost its actuality, especially since the notion of civilization itself is considered in the meaning of the development of the creative forces of mankind, that is inseparable from the process of humanizing culture.

It is known, the post-structuralism, which has arisen on the basis of Freud's psychoanalysis and Levi-Strauss's structuralism, has proposed of a completely critical view on culture. The influence of psychoanalysis and structuralism on a theory of the Civilizing Process, elaborated by Norbert Elias, is indeed much less than on postmodern criticism. But, both Elias and representatives on poststructuralism, in particular Michele Foucault, point to the leading role of social structure and of its complex differentiation in the elaboration of rigorous behavioral norms and in the formation of no less complex immanence.

Similar to the recognition of culture evolution in the socio-historical sense, that found a brilliant confirmation in Elias's theory of the Civilizing Process, the fact has become obvious for a lot of modern researchers that "this Self" is no more than the social subject, which built up by Civilization. This is exactly what unites both above mentioned thinkers, which are confident in historical sociogenesis ("shaping") of individual, that is both of them argue the existence of close relationship between psychic process and social one.

However, there are things in these studies, that distinguish them from each other explicitly. As one noted before, Elias considers the civilizing process as a process of developing a behavioral culture "in the direction of increasing hardening and differentiation of people's control over their affects" (Sajtarly, 2019: 72), then according to Foucault, the term of civilizing is, mainly, associated with the process of softening the social sanctions.

It is referring that for Elias the humanizing of culture directly associates with civilizing process, which, as he believes, is due, primarily, to the cultural transformation of the Western "elites". Like Freud, he is convinced that civilizing process is stratified in the sense that it is, explicitly, not caused of activities on so-called "underprivileged classes". Moreover, the issue of "softening" of Western culture as its major feature and achievement here is leveled with of civilizing process, defined by Elias, mainly, as the process of developing the high behavioral standards, which, from his view, lead to strengthen of emotional control and modeling within individual. According to Elias, the phenomenon of "courtesy" itself can already be regarded as a step on the way, leading to the method of modeling of our drives, a step on the way to civilization.

In other words, from Elias's point of view, the civilizing process does designate to both the humanizing of mores (when, for example, the passion for violence are replacing by passion for accumulation), and ennoblement of the Western culture in a sense of arising and spreading of high behavioral patterns, whereby it began to be considered as superior of all others. Based on the said-above, Elias 
insists on elaboration of a "specific science", titled as a "historical social psychology" (Elias, 2001, vol. I: 8), which focuses on "psycho-genetic and socio-genetic studies at the same time", since from his point of view, the research of the society beyond the human mentality, is to the incorrect.

Reasoning about origins of Western culture, Elias supports of his teacher Karl Mannheim, who, as wellknown, argued that any system of values depends on class (group) interests, which it reflects. It is known too, that Mannheim was an ardent opponent of Weber and subjected to doubt the thesis of existence of the rational knowledge that was to the free from any values. Elias is partly agreed with Weber in his critic of economic approach, supposing that the thesis of Marx about the reducibility of the driving forces of history to only sphere of production and economic interests is erroneous. But, he uses the postulates of historical materialism in explaining the genesis of "Courtly Society" and the culture that is corresponded it. First and foremost, he refers to the economic transformation, that in European countries had have done since the late Middle Ages and intensified in the Renaissance in connection with the development of money economy and manufacturing, and the formation of a centralized tax system and power, that is, the State. All this, in the past, has led to essential modifications in social structures of Western societies, especially in the systems of political power.

In his works Elias argues that transformation of production relations has provided not only the growth of the economic power of the bourgeois class, but also helped to strengthen the political position of the monarch and his courtly aristocracy. Having received a monopoly on collecting taxes, the monarch balanced moderately the claims of the nobility and the bourgeoisie. He held all power in his own hands by skillful manipulation: bourgeoisies for their submissiveness received from him the aristocratic titles and privileges; the nobility was provided decent financial support that, according Elias, has contributed to the strengthening of the institution of "Courtly society."

The financial dependence of courtiers on the royal treasury aggravated competition and the desire to serve the "overlord" as best as possible. Thanks to the development of the monetary economy, which strengthened the financial positions of the bourgeoisies and the monarch, the immanent of structure of the representatives of these social strata began to change significantly: the struggle for the king's special favor intensified competition that led to the need to calculate each step and weigh each word, both in the presence of enemies and the suzerain, hence, to restrain the impulsivity and emotions as much as possible.

The entire system of politic and economic power in era of Absolutism contributed to formation of specific refinement of tastes, which was called then as the "delicacy". In the situation of person dependence on the suzerain, the courtiers will have to elaborate the such behavioral standards that demonstrate their total devotion and respect. Elias analyses of the structure and examples of high behavioral standards in detail. As we've pointed out before, content of these standards (patterns) was defined of terms of "courtesy" and "rationality", that is ethic imperatives, based on the affective alienation, exact calculation and hard self-control (Ishchenko, 2016: 105).

Another very important his argument is related to statement about "class character" of culture, especially of Western one, in the history of which two main "ethos" aristocratic and bourgeois - were formed. Elias believes, that another significant factor, which influenced the development of noble culture in general, should be considered a sense of social superiority. When the knights actually turned into "courtiers," it was created a pyramidalhierarchical system of feudal society, which found its expression in the "tables of ranks". Nobles looked for distinguish themselves not only as the ruling class, but as the upper-class.

Thus here, Elias has to recognize that also a growing sense of class superiority led to create of high behavioral patterns, for example, to standard of "gallantry":

We clearly see that "delicacy", the growing sensitivity to the spoken and written words, to the nuances of rhythm, sound and meaning, arise first in a small circle of "good" court society. For this circle, such sensitivity and "good taste" are associated with prestige: everything that hurts their sensitivity, "stinks the bourgeois", is to the socially inferiority ... (Elias, 2001, vol. II: 300).

In other words, not only the development of feelings of "unpleasant" and "shameful", expressed in physiological repugnancies, became an effective mechanism for refinement of human sensuality, therefore the intensification of civilizing process, but also a class sense of social exclusivity. This is weightier argument that is opposite to the civilization interpretation of culture, based on, as well know, the overstatement of the influence of religion, which willingly supported by Max Weber. In spite of a certain sympathy to Weber's ideas, Elias appeals to the postulates of "historical materialism" in his attempts to clarify of generating and dynamic of Western culture.

Though, it is worth remarking that in his sociocultural studies Elias refers to only certain period of genesis of Western society, named as Absolutism and only a certain social group, named as "courtly society". The matter of exactly how the anthropological type and culture changed under conditions of "modern society", as a matter of additional, more powerful and total means of cultural influences, here is ignored.

In the developing of alternative socio-cultural theory, a no less famous thinker of twentieth century, namely, Michel Foucault, pays the most attention to other mechanisms of social control over individuals. Unlike Elias, he emphasizes the importance of repressive-disciplined approaches in institutional modeling both immanent structure of individuals and their bodies with the difference that the topic of modeling "docile souls" here was obvious replaced by the topic of modeling "docile bodies".

Contrary to Elias, Foucault begins his exploration from so-called "underprivileged, suppressed classes", which always were to the most dangerous for upper stratum. What is the history of their "humanizing"? How much softened their impulses and mores?

Nevertheless, Foucault explicitly avoids a direct formulation of these questions. Perhaps, he appeals to social "bottoms" in order to emphasize that there was another history of civilizing, which wasn't so "gallant", rather, contrary, it was barbaric and immensely bloody. ...In his notorious study, titled as "Discipline and punish. The Birth of the Prison" Foucault (1977) as if reminds that so-called upper classes themselves were embodiments not only high behavioral standards, but they also were such institutional "minority", which employed most sophisticated in its cruelty the devices of public control and submission, that is to say, quite opened practices of "corporal impact" on human souls.

In other words, above-mentioned history was carried out by means of other instruments, which were more common, and which was directly due to economical 
transformations in leading Western countries. He is, first of all, referring to industrial revolution that caused a need in saving of human's lives, while in economics of preindustrial mode ("régime") "labor power, and therefore the human body has neither the utility nor the commercial value that are conferred on them, in an economy of an industrial type" (Foucault, 1977: 54).

So, Foucault tends to stronger economical determinism in clarification of civilizing process, in particularity, he states that the generating of new economics causes the new technology of controls, in relation to that Foucault operates with the concept "economy of the power". He considers that in condition of industrial production the gentle way in punishment became inevitable, since became more useful to make the human body serve the State "in a slavery": without eliminating a life, the State should appropriate and turn out it into "a sort of rentable property".

Precisely the capitalist economy led to so-called "accumulation of men", that is substitution of preindustrial "gloomy festival of punishment" for disciplines, which Foucault defined as the methods, assuring "the constant subjection of bodily forces and imposed upon them a relation of docility-utility" ( $p .136)$, and in this regard he notes:

The growth of capitalist economy gave rise to the specific modality of disciplinary power. In fact, the two processes - the accumulation of men and accumulation of capital - cannot be separated, it would not have been possible to solve the problem of accumulation of men without the growth of an apparatus of production capable of both subjecting them and using them, and conversely (Foucault, 1977: 221).

Thus, according Foucault, phenomenon of humanization is to the effect of industrial transformation of western societies, that is the humanism is economic-caused concept. In fact, industrial capitalism generated the humanism in a sense of a special relation to the body, expressed in an effort to preserve it as a resource for the continuous production of surplus value.

The mentioned class contexts in Foucault's works are obviously leveled with functional one, that can be explained by the implicit critical context of his whole philosophy as such. In other words, postmodernist is not much interested in studies of the fluctuation and advancing thresholds of shame, for example, or of etiquette manuals. He discusses the methods, which made possible the meticulous control of the operations of human body and over whole individual.

Nevertheless, both Elias and Foucault try to prove that the human mind, or so-called mentality is to the relative and historically variable, which can call into the question of conventional Western "rationality" as a constant its trait. As Elias remarks, the civilization and associated with this rationalization, is not to the effect of some metaphysic's mind, or "long-term planning". The theory of Civilizing process itself means "the emphasizing of existent connection between changes in social structure and changes behaver and mental habitus of person".

Moreover, under the conditions of the post-modern era, this rationality, step by step, is replacing by the cult of affective freedom. In other words, contemporary "anthropological type" can scarcely be described in the terms of mentioned by Elias, that is, in the terms of behavioral rationality, "self-constraint", "civilities" and "propriety".

One should be noted that in many contemporary societies, the social relationship has lost its personal context. In other words, the relations in such societies are no longer based on close attachments and person interdependences for the most part, vice versa, they are impersonal, functional, indifferent, and perhaps even are "schizoid". Not by chance, some contemporary scientists had to admit "that the civilizing process, which they summarized as increasing self-controls, had changed direction because now, the codes of behavior and feeling were loosening up... self-control diminishing" (Wouters, 2010: 58). The schizoids (as postmodernists note) are orientated only to production flows, but not to "persons", in relation to that has elaborated an alternative approach, named the "schizo-analysis". It is very different from the existential Da-sein analysis and psychoanalysis, which are dominated in philosophical theory, but have become outdated and generally, have lost its meaning.

A very powerful poststructuralist argument of "schizoanalysis" is that in the high-developed societies neither morality nor even culture is a factor of social life that determines their ideology and political components. The traditional culture was grounded on strict prohibitions and, by means of its ascetic imperatives, perhaps, it provided of arising in the individual's psychological structure of "a habit to give up of desire" (Freud). That is why, it is very doubtfully, that the postmodern culture, which is to the "hedonistic" in its core, is capable of "modeling" to strong self-control and strong self-restraint in individuals. Rather conversely, it contributes to the rejection of the individual from public interests, since here the power of desire prevails, but not reason and obligation.

Referring to current cultural decadence, which is indicated by majority of present-day thinkers, we have to admit that there is an essential difference between such phenomena as humanizing process and humanizing of man. The thing is that the civilizing process, which does significate the humanizing of fundamental sociocultural institutions in the sense of their essential "softening", unfortunately, did not cause by itself the fundamental restructuring of libido.

\section{Originality}

Originality of this investigation is to the define of the similarities and differences Elias's and Foucault's accounts of the civilizing process, as a result of which it was clarified, that it is direct connected with phenomenon of humanization, designated as historical process of strengthening of affective control and essential softening of coercive practices.

\section{Conclusions}

Summarizing of all thought above, we can state that the critical thinking of Foucault and also the viewpoint, which was expressed in a so-called theory of Civilizing process, have become a valid ground on recognition of the $h u$ manizing of social norms and mores, and consequently the cultural evolution in the socio-historical terms. In reflections on genesis of Courtly Forms of Conduct, Elias perfectly demonstrated that so-called Civilizing process was due to, primarily, the humanizing in the sense of longterm process of changes in human behavior under influence the social figurations people form together. Precisely the system of social interdependences, that is the high-different social structure, its evolutional transformations have civilized of human behavior, speech, lives, taste and so on, made him much less destructive. If, however, Elias's theory of culture is to the system of concepts and argumentations that are intend to prove the fact of evolution of human being and human civilization, while of Foucault's post-modern study is a story about evolution of social coercing, accompanied by the desire of the ruling elites to absolute domination. 


\section{REFERENCES}

Binkley, S., Dolan, P., Ernst, S. \& Wouters, C. (2010). The Planned and the Unplanned: A roundtable discussion on the legacies of Michel Foucault and Norbert Elias. Dublin Institute of Technology, Foucault Studies, (Vol. 8), 53-77. (in English)

Cavalletto, G. (2016). Crossing the Psycho-Social Divide (Freud, Weber, Adorno and Elias). London: Routledge (in English)

Chita, Dan Alexandru (2012). The Birth of the Subject: Michel Foucault and Norbert Elias. Hermeneia: Journal of Hermeneutics, Art Theory \& Criticism, 12, 163-177. (in English)

Elias, N. (2001). The Civilizing Process: Sociogenetic and Psychogenetic Investigations, (Vol. I). Moscow; St. Petersburg: University book. (in Russian)

Elias, N. (2001). The Civilizing Process: Sociogenetic and Psychogenetic Investigations, (Vol. II). Moscow; St. Petersburg: University book. (in Russian)

Ishchenko, O. (2016) Social and structural dependence of European cultural tradition. Herald of Kyiv National University of trade and economics, 2 (106), 96-108. (in Ukrainian)

Jimenez-Lopes, E. (2017). Constructive exploration among minds that recognize the civilizing Crisis: Searching to create a humanized civilization / IS4IS 2017 GOTHENBURG-CONFERENCE FLYER. (in English)

Paulle, B., Emirbayer, M. (2016). Beneath rationalization: Elias, Foucault, and the body. European Journal of Social Theory, 19, 39-56. doi.org. /10.1177/1368431015602355 (in English)

Sajtarly, I. (2019). The psychological structure of individual as a subject matter of the postmodern socio-cultural analysis. Herald of Kyiv National University of trade and economics, 1 (123), 6979. doi.org./10.31617/visnik.knute.2019(123)06 (in English)

Foucault, M. (1977). Discipline and Punish: The Birth of the Prison. New York: Pantheon Books. (in English)

\section{LIST OF REFERENCE LINKS}

Binkley S., Dolan P., Ernst S. \& Wouters C. The Planned and the Unplanned: A roundtable discussion on the legacies of Michel Foucault and Norbert Elias. Foucault Studies. 2010. vol. 8: P. 5377.

Cavalletto G. Crossing the Psycho-Social Divide (Freud, Weber, Adorno and Elias). London: Routledge, 2016. 300 p.

Chita Dan Alexandru. The Birth of the Subject: Michel Foucault and Norbert Elias. Hermeneia: Journal of Hermeneutics, Art Theory \& Criticism. 2012. Issue 12. P. 163-177.

Элиас Н. О происхождении цивилизации. Социогенетические и психогенетические исследования. М.; СПб.: Университетская книга, 2001. Т. 1. 2001. 332 с.

Элиас Н. О происхождении цивилизации. Социогенетические и психогенетические исследования. М.; СПб.: Университетская книга, 2001. Т. 2. 2001. 382 с.

Іщенко О. М. Соціоструктурна зумовленість європейської культурної традиції. Вісник Київського національно-економічного університету. 2016. №2 (106). С. 96-108.

Jimenez-Lopes E. Constructive exploration among minds that recognize the civilizing Crisis: Searching to create a humanized civilization. IS4IS 2017. GOTHENBURG-CONFERENCE FLYER.

Paulle B., Emirbayer M. Beneath rationalization: Elias, Foucault, and the body. European Journal of Social Theory. 2016. vol.19. P. 39-56. doi.org. /10.1177/1368431015602355

Sajtarly I. The psychological structure of individual as a subject matter of the postmodern socio-cultural analysis. Herald of Kyiv National University of trade and economics. 2019. № 1 (123). P. 69-79. doi.org./10.31617/visnik.knute.2019(123)06

Foucault M. Discipline and Punish: The Birth of the Prison; [translated from the French by Alan Sheridan]. New York: Pantheon Books, 1977. $333 \mathrm{p}$.

\title{
Інна Сайтарли,
}

Київський національний університет імені Тараса Шевченка (м. Київ, Украӥна) e-mail: inna.saitarly@gmail.com,ORCID 0000-0001-8253-4898

Олена Іщенко,

Київський національний університет імені Тараса Шевченка (м. Київ, Украӥна) e-mail: rebluesun@ukr.net,ORCID0000-0003-3832-2403

\section{ФІЛОСОФСЬКИЙ ПОГЛЯД НА ГУМАНІЗАЦІЮ ЧЕРЕЗ ПРИЗМУ ЦИВІЛІЗАЦІЙНОГО ПРОЦЕСУ (НА ЗАСАДАХ СОЦІАЛЬНО-АНТРОПОЛОГІЧНИХ ІДЕЙ Н. ЕЛІАСА ТА М. ФУКО)}

\begin{abstract}
Метою даної публікаціїє розгляд взаємозв'язку між гуманізацією та цивілізаційним процесом, що базується на працях Еліаса та Фуко. Теоретичний базис цих наукових розвідок складає порівняльний аналіз, феноменологічний підхід та узагальнення. Наукова новизна дослідження полягає у виявленні схожості та відмінності у розумінні Еліасом та Фуко цивілізаційного процесу в контексті прояснення головних смислів гуманізації. Висновки. Ми вважаємо, що в антропологічних та соціокультурних поглядах Еліаса та Фуко існує певна спільність. Насамперед, обидва автори підтримують тезу про мінливість так званої людської природи, її обумовленість соціоструктурними змінами. Західноєвропейські філософи Еліас та Фуко переконані в тому, що історія культур ("цивілізацій") - це історія інституціональної боротьби з людськими потягами та бажаннями 3 метою їх "моделювання" у відповідності з загальноприйнятими соціальними імперативами. Не лише Еліас, а також постструктураліст Фуко ставить під сумнів цивілізаційну інтерпретацію культури як таку, відтак будь-яку спробу погляду на культуру як на продукт виключно релігійних ідеалів та традицій. Еліас переконливо довів, що культура залежить від реального соціального ландшафту, істотна трансформація якого впливає на істотну трансформацію усієї системи цінностей. Врешті-решт, в рамках цих досліджень, культури розглядаються 3 точки зору ступеня їх цивілізованості у сенсі "людяності", що зазвичай визначається ними як довготривалий процес раціоналізації поведінкових моделей за умов посилення афективного контролю та самоприборкання, а також особливого ставлення до болю, як у його фізіологічному, так і в моральному сенсі. Інакше кажучи, найбільш значимим показником рівня цивілізованості, відтак гуманізації суспільства і його культури є ставлення у ньому до насилля.

Ключові слова: цивілізаційний процес; гуманізм; гуманізація; культура; генеалогія; дискурси влади; дисципліни; раціональність.
\end{abstract}

(C) Sajtarly Inna, Ishchenko Olena

Надійшла до редакції: 02.09.2019

Прийнята до друку: 25.09.2019

ISSN 1728-9343 (Print)

ISSN 2411-3093 (Online)

SKHID No. 5 (163) September-October 2019 